\title{
Chorus Lines: Catalogues and Choruses in Archaic and Early Classical Hexameter Poetry and Choral Lyric
}

\author{
Deborah Steiner
}

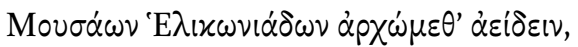

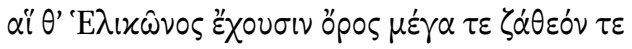

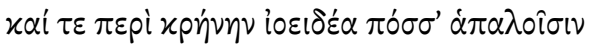

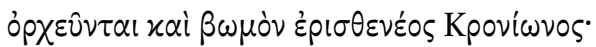

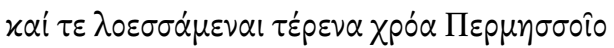

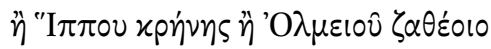

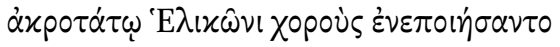

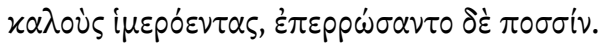

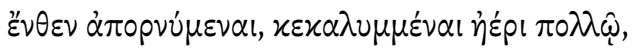

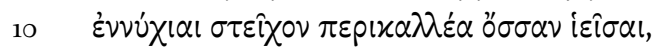

Let us begin to sing from the Heliconian Muses, who possess the great and holy mountain of Helicon and dance with supple feet about the violetdark spring and the altar of Cronus' broad-strengthed son. And having washed their tender skin in Permessus or the spring of Hippocrene or holy Olmeius, they perform fair, desire-instigating choral dances and ply their feet. Setting out from there, enshrouded in much mist, they process by night, emitting their very beautiful voice.

HES. Theog. 1-10

Hesiod's Theogony opens in a manner that sharply differentiates it from its Homeric counterparts: in place of the singular "goddess" or "Muse" whom the Iliad and Odyssey proems invoke, Hesiod's divinities form a plurality. More than this, the opening vignette depicts the Muses engaged in a particularized activity, performing a ring dance around a body of water and altar with the "tender feet" distinctive of choral maidens in archaic epic and lyric poetry. ${ }^{1}$

1 Cf. Alcm. fr. 3.10. 
The divinities' presentation as an archetypal chorus continues through this opening visualization: a few lines on, we meet them "making dances," plying their feet in the manner of Iliadic and other choral dancers, ${ }^{2}$ and like the prototypical chorus on the shield of Achilles, and those that follow in the lyric corpus, the Muses' ensemble is both beautiful and desire-instigating. ${ }^{3}$ Even as the performers sing - thereby satisfying the later Platonic definition of choreia as "song-dance" (Leg. 654a) — their motion changes: now, marching ( $\sigma \tau \varepsilon i ́ \chi \omega$ regularly denotes orderly, ranked movement) down from the Heliconian heights, the deities process. Here poetic content and choral formation coincide. Just as the Muses perform a reverse Theogony, beginning at the succession struggle's end as they move from the mountain to lower land, so they invert the regular sequence that determines the movements of a chorus: first the linear procession to the sacred site, and then the ring dance, typically performed around an altar or other center point, on reaching its destination. The Heliconian Muses, by contrast, quit the "altar of Cronus' son" and the divinely-inhabited bodies of water (so often the site of choral dancing, particularly by nymphs) so as to descend into the mortal, secular realm. The song sung by the goddesses as they journey downwards - a last-to-first inventory of the Olympians and those preceding them-already supplies the template for the mode of discourse that Hesiod will adopt in the poem that follows: the catalogue or list.

The Theogony's opening scene succinctly exemplifies the larger phenomenon explored in this chapter, the copresence of choruses and catalogues in archaic and early classical poetry. For all that the catalogue is regularly viewed as an element integral to hexameter poetry and among the hallmarks of that genre, both in Hesiod's proem and elsewhere, choruses regularly appear when such lists occur, whether as performers of the itemized accounts and/or as the subjects of a poet or internal speaker's "catalogic" presentation. In the twofold argument made here, the coincidence between troupes of singer-dancers and a catalogue depends in no small part on the "incipient chorality" that the enumerative device possessed in the archaic Greek imaginary, and calls into question the assumption that several of the catalogues in choral poetry necessarily derive from prior hexameter sources; rather, I propose, both Homeric and Hesiodic lists may take their cue from, or be informed by, choral performances staged before a civic audience on ritual occasions. More broadly, in

2 E.g. Il. 24.616, Hymn. Hom. Ven. 261.

3 Il. 18.49o-561; Alcm. fr. 3. For representations of maiden choruses in the lyric and dramatic corpus recapitulating the terms used here, see Swift $2016 \mathrm{~b}$.

4 I borrow the expression from Power 2011: 75 . 
the bilateral exchanges my discussion suggests, the introduction of a catalogue within hexameter and choral poems offers an instance of what might be styled "generic contamination" or boundary crossing, whereby a composer in one genre embeds within his or her piece a mode of discourse drawn from a very different performance tradition. On these occasions, I argue, the list's generic underpinnings remain discernible in its diction, design, speaker/singer, and/or the manner or context of its presentation.

The discussion that follows falls into two sections, the first given over to close readings of three passages, one from hexameter epic, two from fifthcentury choral compositions, that variously illustrate the generic exchanges between lyric and hexameter song and feature indicators of the stylistic hybridity that results from these poetic interactions. Part two goes on to propose some underlying reasons for the phenomenon just observed. Drawing attention to continuities between the morphologies of catalogues and chorusesthe designs and formations both adopt, the relations between the individuals or items in a list and the singer-dancers making up the choral ensemble, the hierarchies structuring the two assemblages - in both the poetic and visual repertoires, it suggests that these features may explain the reasons why, as my opening example from Hesiod and the passages treated in section one demonstrate, hexameter epic looks regularly to a chorus to perform a list and choral lyric to the monodic genre when incorporating a catalogue into its song and dance.

\section{"Generic Contamination" in Homer, Bacchylides, and Corinna}

A single overarching question informs my close readings of three passages from archaic and classical poetry: if my claim for generic commingling is correct, then how might we discern in these lines their authors' acts of appropriation and what structural, stylistic, dictional and other generic "fingerprints" reveal their borrowings? Or, more specifically, what in the epic passage points to its choral derivation or, as argued here, coexistence in the form of a composition performed by a chorus before a civic audience; and, conversely, where do the choral poets acknowledge the hexameter tradition's use of the catalogue and their debts to that genre? Through a detailed examination of each passage, I hope also to suggest some of the reasons fueling a poet's choice to import elements from a different generic and performance tradition and to observe the dividends that the practice pays.

For the chorality informing the most "purple" of all Homeric catalogues, my reading takes its cue from a treatment of the passage by Bruce Heiden and 
builds on his discussion. ${ }^{5}$ As part of a larger argument that aims to demonstrate the curiously populist orientation of the Catalogue of Ships, its privileging of the common soldiers and communities they have left behind over the aristocratic heroes who dominate the remainder of the poem, Heiden suggests that the Catalogue does indeed conform to its characterization in Cedric Whitman, who styles it a "hymn to the army." 6 For Heiden, the designation is more than merely rhetorical. Rather, the list exhibits its "hymnal" and collective dimensions by its inclusion of features more typical of lyric than hexameter poetry and most closely parallels a lyric lament, a threnody such as would be performed by a civic chorus at a funerary ritual on behalf of those who had lost their lives fighting abroad. Among the chief lyric giveaways identified by Heiden are: the introduction of the refrains so characteristic of choral laments and which invest the movements described with a "rhythmic performance dimension comparable to dance"; the ways in which the poet invites us to view the vessels not just as soldiers advancing in their ranks but as members of choral

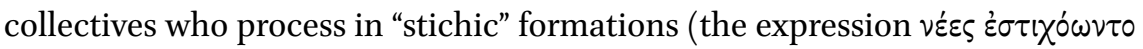
closes four of the entries); and the use of diction suggesting parallels between the structure of the crews and those of choral ensembles and identifying those who assemble the contingents as choregoi-like leaders to the troops that "follow". 8 While Heiden focuses all but exclusively on the appeal to the Muses and the subsequent inventory, I want first to look at the events immediately preceding the invocation before noting some additional elements in the list consistent with a lyric composition.

The preliminaries to the Catalogue prepare the ground for what follows, alerting us to the way in which the poet prefaces his enumeration by ordering its multiple items and by suggesting the presence of a chorus leader. Following Nestor's proposal that the heterogeneous mass of assembled troops be divided by tribe and phratry (362) and the army's sacrifice and meal, the leaders carry

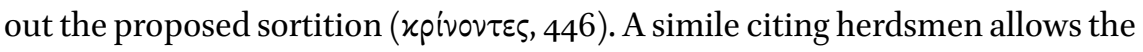
audience to visualize the action, with the addition of a fresh term evocative of a decking out that introduces an aesthetic dimension to the arrangement (474$476)$ :

5 Heiden 2008, esp. 145-152.

6 Whitman 1958: 262, cited by Heiden 2008: 129 .

7 Heiden 2008: 149 .

8 Heiden 2008: 149 . 


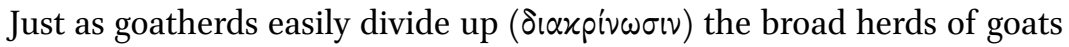
when they mingle on the plain, even so the leaders divided and marshaled

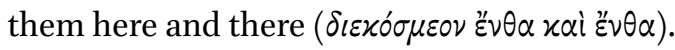

Thucydides uses $\delta เ \varepsilon x o ́ \sigma \mu \varepsilon เ$ of the organization-cum-arraying of the Panathenaic procession (6.57.1), while Xenophon of Ephesus' description of the pompe celebrating the Ephesia selects the verb in its uncompounded form for the simultaneous ornamentation and orderly positioning of the chorus in the line (Ephesiaca 1.2.4). The Athenian Xenophon, speaking of how the good housekeeper groups her different pots and pans according to their kind prior to their inventorying, spells out, albeit half fancifully, connections between the act of division, orderliness, and the aesthetic and expressly rhythmic harmony (so eüpu$\theta \mu o v$, a term regularly used in the context of mousike and groups of performers moving in time) that results, and a choral arrangement (Oec. 8.19-20):

No serious man will smile when I claim that there is beauty in the order

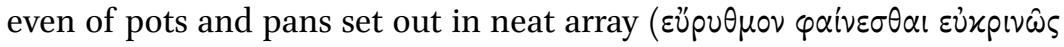
$\chi \varepsilon \mu \varepsilon^{\prime} \nu \alpha \varsigma$ ). There is nothing, in short, that does not gain in beauty when

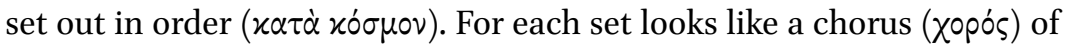
utensils, and the space between the sets is beautiful to see, when each set

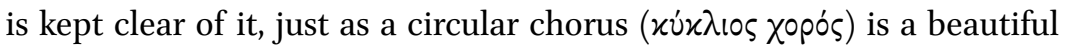
spectacle in itself.

Indeed, kosmos belongs among the defining features of a chorus, the quality succinctly foregrounded in the account given by the messenger in Euripides' Bacchae, where he remarks of the maenadic troupe responding to Agave's choregic summons: "they started up, upright, wondrous to behold in their

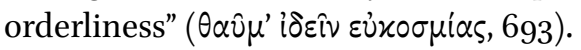

Choral ordering frequently depends on the choregos, and so the troops' disposition in Iliad 2 ends by spotlighting this figure standing among the soldiery (477-481):

Lord Agamemnon there among them, like to Zeus delighting in thunder with regard to his eyes and head, and to Ares in his waist and Poseidon in his chest, just as a bull is preeminent among the herds. For he is conspic-

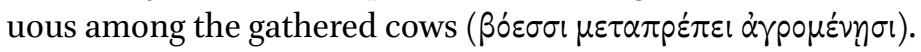

The term used of Agamemnon, $\mu \varepsilon \tau \alpha \pi \rho \varepsilon \varepsilon \pi \varepsilon$, regularly signals the choregos, distinguishing Nausikaa as she leads her attendants in their dance (Od. 6.109). With a very similar expression, Agido is styled $\dot{x} x \pi \rho \varepsilon \pi \eta \dot{\zeta}$ in Alcman's Parthe- 
neion (fr. 1.46), and even as the Homeric hero-bull is conspicuous among the cows, so this chorus-leader "appears outstanding as if one placed among a grazing herd a perfect horse, a prize-winner" (45-48). ${ }^{9}$ It is the fourth-century Xenophon again who explicitly compares a company of soldiers, where each man occupies his appointed place within the larger group, and the well-functioning choral ensemble. Approving his son's proposal to arrange competitions in the warlike exercises required of soldiers in battle, Cambyses remarks that, by virtue of this regimen, "you might see military companies that are just like

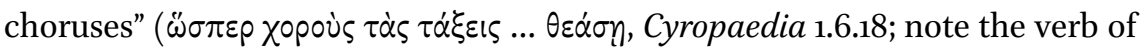
spectatorship appropriate to chorus viewers). Still more apposite is the return to the analogy in Cyropaedia 3.3.70: in disarray following the failure of a first assault, the troops "halted in their regular position, knowing much more accurately than a chorus each one the spot in which he should stand" ( $\pi \circ \lambda \dot{\nu} \mu \alpha \hat{\lambda} \lambda \circ \mathrm{v}$

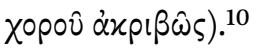

The Iliadic scene of the troops' arrangement closes just before the invocation to the choral Muses, the transition point between the narrative and the start of the Catalogue. In the divinely channeled list that follows, the chorality latent in the preceding episode becomes more marked. Not only, as Heiden well observes, do the naval contingents resemble members of choral collectives processing in their ranked formations, but we witness the stationing of these assemblages when they reach their destination, where they stand waiting to perform anew. In his account of the Boeotian contingent at 525, the poet

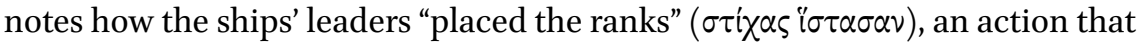
has a second sounding when Ajax similarly positions his twelve ships alongside another group: "and he, leading [twelve ships], positioned them where the

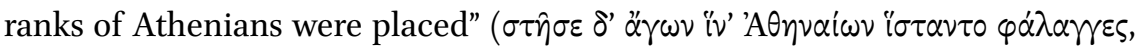
558). The verb used in both phrases has a choral dimension of its own, supplying the vox propria for the setting up, deploying, or instituting of a chorus in the

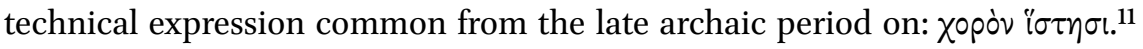
The kosmesis that occurred in the troops' sorting-cum-decking-out now determines Menestheus' conduct; the Athenian hero receives special mention for his skill in arranging/adorning (

9 For the suggestion that it is the poet-choregos who positions Agido here, see Peponi 2004: $313-315$.

$10 \quad$ Cf. Xen. Mem. 3.4.4.

11 See Nagy 1990: 361-362; Calame 1997a: 45; and particularly Myers 2007; note too Peponi 2004: 315; Kavoulaki 2011: 371-373. The first extant usage of the term appears in Pind. fr. $5^{2 b}$.99.

12 Cf. Pind. Pyth. 9.118 for a choregos who similarly adorns ( $(\circ \sigma \mu \eta \dot{\sigma} \sigma \alpha \varsigma)$ his lead dancer in an agonistic event. 
an agonistic context - only Nestor can "vie" ( bination of terms positions the heroes as rival choregoi seeking to outdo one another with the brilliance of their choruses and their aesthetically pleasing deployment. Indeed, later poets and prose-writers would respond to and realize the choral dimension discernible in the Homeric enumeration: both the parodos of Euripides' Iphigenia at Aulis and Thucydides' account of the Sicilian armada gathered at the Piraeus (6.30-32) acknowledge their Homeric "catalogic" template while casting their respective fleets, crews, and expedition leaders as so many rivalrous participants in a choral performance. ${ }^{13}$

If Heiden's larger claim is correct - that together the accumulation of choral terminology and the Catalogue's generically heterogeneous stylistic features turn the list into something approximating a collective song-and-dance that celebrates those whose death at Troy their townsmen in their homelands mourn in choral performances ${ }^{14}$ — then the possibility of a further convergence between a choral performance and a distinctly different poetic tradition opens up. As Joseph Day reminds us, these laments might be transcribed in monumental form, now assuming the shape of inscribed epitaphs - this a genre with conventions of its own which may incorporate a roll call of the dead-where individuals would encounter and vocalize them anew. ${ }^{15}$ It is no happenstance that the inscription on the Ambracian cenotaph analyzed by Seth Estrin in this volume and that, in Day's suggestion, would originally have taken the form of a choral performance, lists the names of the four citizens who died abroad while engaged on a mission for their polis.

As for the impetus behind the Homeric poet's incorporation of a choral threnos, the embedding of this different genre not only suits the nature of those whom the aoidos begins by invoking as overseers of the catalogue to come, the collective Muses who regularly perform laments on the occasion of funerary rites (e.g. Odyssey 24.6o-61). More than this, the act of transference allows the monodic singer to meet the challenge rehearsed in that invocation, effectively granting him the multiplicity of tongues and mouths ( $\delta \dot{\varepsilon} x \alpha \mu \dot{\varepsilon} \nu \gamma \lambda \hat{\omega} \sigma \sigma \alpha l, \delta \dot{\varepsilon} x \alpha \delta \dot{\varepsilon}$ $\sigma \tau{ }^{\prime} \mu \alpha \tau$, 489) that he cites as prerequisites for the performance of so outsized a catalogue, thereby appropriating for his single person the vocal capacities that belong to a choral ensemble.

The amalgamation of the two distinct genres and performance traditions is no less evident in my examples from choral poetry, both featuring a single

13 See Steiner 2018 for these and other examples and, on the Iphigenia at Aulis, Weiss 2018: 193-205.

14 Heiden 2008: 150-151.

15 Day 2007. 
parthenaic group, the nine daughters of the river god Asopos. As I detail elsewhere, in compositions by fifth-century choral poets as well as in a Euripidean stasimon ( $H F$ 781-789), these maidens repeatedly serve as objects of "choral projection," supplying one among the archetypal troupes of singer-dancers whom latter-day ensembles select as models. ${ }^{16}$ But a paradigmatic choralityalso visible in contemporary artistic representations where her sister Asopids dance in choruses during the abduction of Aegina ${ }^{17}$ —is not the only characteristic assigned to this sorority. Instead, as the passages from works by Bacchylides and Corinna treated here illustrate, poets may also choose to frame them within a catalogue, introducing Asopos' daughters and their histories in the form of a list. In the standard view, this mode of presentation results from both composers' debt to a preexisting hexameter source, the Pseudo-Hesiodic Catalogue of Women, where, following Martin West's broadly accepted reconstruction, ${ }^{18}$ the Asopids were a central presence in the poem's fourth book. In place of this straightforward act of appropriation, I suggest that Bacchylides and Corinna are no mere followers: maintaining the sorority's signature chorality, they also draw on the hexameter tradition to which the maidens simultaneously belong, thereby engaging in that "transgenericity" (in Michel Briand's phrase $)^{19}$ already practiced in the Catalogue of Ships.

Bacchylides' ninth ode, composed on behalf of the Nemean victory of Automedes from Phleious, exploits the multiplicity of rivers, or water sources, all bearing the name Asopos: one formed the southern limit of Boeotia, the second, a spring, was located on Aegina, ${ }^{20}$ and the third, featured in the song for the Phleian victor, traced its course through Phleious and originally formed the border between Thebes and Plataea. ${ }^{21}$ This is the Asopos who, along with his progeny, receives explicit praise in lines $40-52$, where the singers rehearse how the river-god's renown has traveled to the far points of the earth, further stoked by the fame of his daughters. Invoking the deity, the singers hail their addressee before beginning their celebration (47-65):

16 Steiner forthcoming. Among the examples I cite, note particularly Bacchyl. 13.77-95 SM and Pind. Nem. 3.1-16.

17 E.g. a red-figure stamnos of ca. 475-425 (Bochum, Ruhr Universistät, Kunstsammlungen S1172), or a column-krater of ca. 46o attributed to the Boreas Painter (New York, Metropoli$\tan$ Museum 96.19.1).

18 West 1985: 100-103. See too Larson 2002: 139-140.

19 Briand used this phrase in his paper at the conference on which this volume is based.

$20 \quad$ See Fearn 2007: 102-105, building on Privitera 1988.

21 Hdt. 7.199-200 also mentions the existence of a Thessalian Asopos that flowed into the Gulf of Malis. For discussion see Kowalzig 2007b: 195-201 and Nagy 2011a: 52-54 (drawing on West 1985: 162-163). 


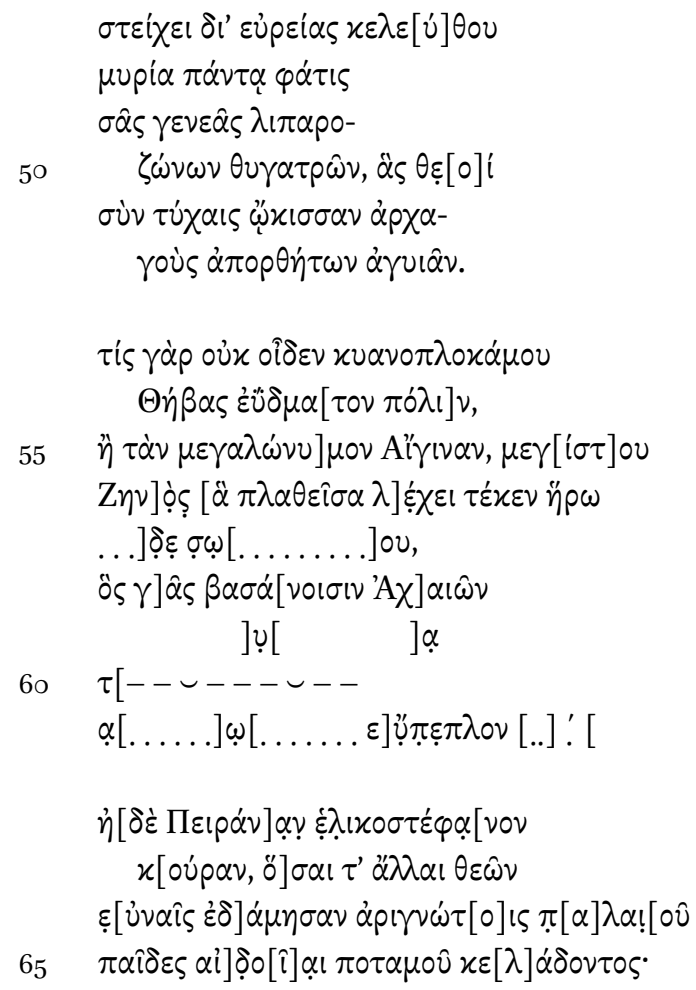

On a wide path travel in all directions the countless reports of your progeny, the shining-girdled daughters whom the gods with good fortune have settled as rulers of unsacked streets. For who does not know of the well-built town of dark-haired Thebe or of the renowned Aegina, who (came to) the bed of great Zeus and bore the hero ... whom the land of the Achaeans by the tests ...? ... fair-robed ... and (Peirene the maiden) of the twining garland, and all those who were mastered in far-conspicuous beds of the gods, venerable daughters of the ancient sounding river.

While the personified river serves, as so often, as the perfect means of establishing a "natural" connection and two-way vector between the victor's home and the site of his win, Asopos' multiple daughters occupy the chief portion of the celebration. As G.B. D'Alessio observes of the lines, ${ }^{22}$ this is the "passage which comes closest to a Hesiodic catalogue in the preserved songs of Pindar and Bacchylides," and he further notes that the $\ddot{\eta}$, retained by some editors at the start 
of line 62 in place of the $\ddot{\eta}[\delta \varepsilon$ printed by Jebb and used here, suggests "that the list may have been coordinated through the disjunctive particle, recalling the $\ddot{\eta}$ oin formula" of the Catalogue of Women that gave the work its alternate name, the Ehoiai.

A catalogue structure continues to inform the passage. Despite the lines' lacunose condition, we can assume that the singers would have listed at least some of the river's progeny: with Thebe heading the enumeration and Aegina next in line, two or even three other daughters would have been named, each accompanied by an epithet. ${ }^{23}$ David Fearn suggests the inclusion of Cleona in line 61, and Peirene, the Corinthian spring, seems a likely candidate for $62 .{ }^{24}$ The catalogue ends in the fashion typical of hexameter lists, with a summary reference to "all those other venerable daughters of the ancient sounding river."

But alongside the choice of a (Pseudo-Hesiodic) catalogue format for the Asopids' presentation, with all the authority and aggrandizement that the hexameter and now canonical Panhellenic source would lend the home-based ensemble in the current composition, the maidens' choral character is no less prominent. Bracketing the geographical-mythical excursus are references to Automedes' victory and its celebration in song and dance on his arrival home. In lines $27-36$ (fully cited below), the singers recall the laudandus' winning cast with the discus before pivoting to the moment of his return to Phleious and

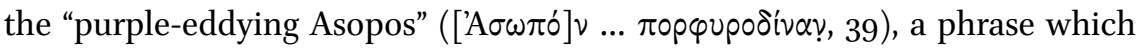
acts as lead-in for the account of Asopos and his daughters. A second matching mention of the river ( $\pi \circ \tau \alpha \mu \circ \hat{v} \chi \varepsilon[\lambda] \alpha \dot{\delta} 0 \nu \tau \circ \varsigma, 65)$ concludes the description of the Asopids, signposting this embedded section's end and a return to where the song left off as the singers resume praising Automedes. With the river and its epithet in final position in the line, the lacunose phrase that follows moves directly back to the present occasion where the "shouts of pipes" ( $\alpha \dot{\nu}] \lambda \hat{\omega} \nu$

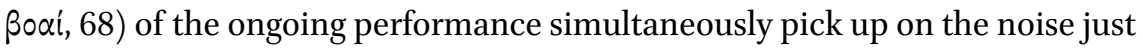
emitted by the water. The bookending of the section introducing the Asopids between two celebrations of the victor not only alerts us to the connections that the poem suggests between the objects of praise, the Asopos, its offspring, and the local boy made good; it also draws attention to choreia as the critical mechanism for the propagation of renown, a counterpart to the extensive (epic) river/genealogical network that Bacchylides has traced out and that, like the water course with its self-multiplication in its progeny, is both synchronic and diachronic in scope.

23 Maehler 1982: 1.186 makes various proposals concerning the other names.

24 Fearn 2003: 361. 
The interfaces between the present-day festivities and the nine Asopids are also visible in the diction of the framed passage, which depicts the maidens in terms that align them with Bacchylides' choreuts and their ongoing performance, and positions the mythical sorority as the originary chorus on whom Automedes' celebrants now model themselves. Styled "shining-girdled"

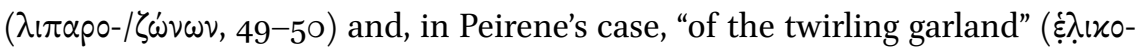
$\sigma \tau \varepsilon \dot{\varepsilon} \varphi\left[\right.$ [vov, 62), ${ }^{25}$ the Asopids' accessories correspond not just to the radiance of the current singer-dancers (the sine qua non of any chorus worth watching), ${ }^{26}$ but perhaps to their circular choreography too. Fresh rotations belong to the maidens' watery progenitor, who, in a striking hapax, has displayed its "purple eddies." Sound as well as movement and sparkle links the different sections: the noise emitted by the river, then echoed by the clamorous pipes, supplies an audible and musical counterpart to the $\varphi \dot{\alpha} \tau \iota$ featured in the description of the river and his daughters' renown.

Nor is this choral "mapping" confined to the Phleian chorus members; while Automodes resembles the parthenoi and their father insofar as he, like them, supplies the object of choral encomium, the visualization of the athlete (his hair similarly garlanded, $\sigma \tau \varepsilon \varphi \alpha \dot{v} \omega, 23)$ at the moment of his triumph in the lines immediately preceding the Asopids' introduction positions him as leaddancer/choregos of the celebratory band $(27-36)$ :

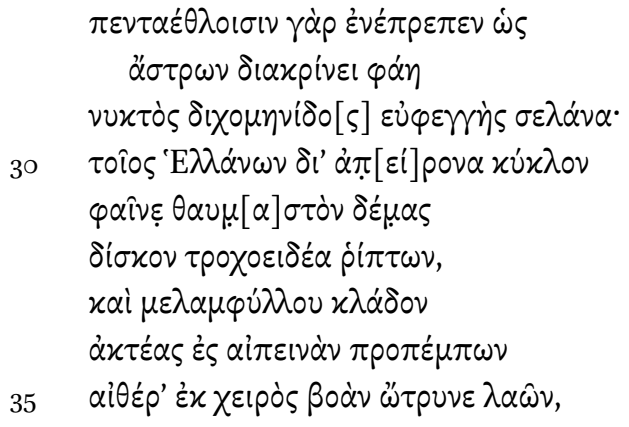

For among the pentathletes he was conspicuous, as the fair-shining moon stands distinguished from (i.e. outshines) the light of the stars in the midmonth night, even so in the boundless circle of the Greeks did he display his awesome form as he cast the wheel-shaped discus, and send-

25 For the choral association of $\dot{\lambda} \lambda \dot{\sigma} \sigma \omega$ and its cognates, see Csapo 1999-200o.

26 See Kurke 2012: 228-229. 
ing forth from his hand the shoot of the dark-leaved elder into the sheer heavens he stirred up the acclamation of the crowd, or when he completed the flashings of the wrestling.

Each and every phrase suits a choregos as portrayed in the earlier lyric (and hexameter) tradition. No less pertinent to choreia than the "conspicuousness" already treated above that sets Automedes apart from the other contestants are the associations of the nighttime sky illuminated by the moon and attendant stars; ${ }^{27}$ whether on the first band of the Iliadic shield or in Alcman's first Partheneion, these constellations are paradigmatic choral dancers, the less brilliant celestial bodies following the lead of, or circling about, their stellar choregos. As commentators note, here Bacchylides also echoes the conceit in Sappho fragment $96.6-10 \mathrm{~V}$, a choral song in which the performers praise a now departed chorus member, ${ }^{28}$ the former première of their troupe; it was in her song-and-dance $(\mu \dot{\partial} \lambda \pi \alpha, 5)$ that the sorrowing Atthis left on Lesbos chiefly took delight. Just as Automedes stands out in his dazzle, so this parthenos-turnedbride maintains her choral preeminence in her new home: "she is conspicuous ( $\dot{\mu} \mu \pi \rho \varepsilon \dot{\pi} \pi \tau \tau \alpha l)$ among the Lydian wives like the rosy-fingered moon ... outshining all the stars" ( $\left.\pi \dot{\alpha} \nu \tau \alpha \pi \varepsilon \rho\langle\rho\rangle \dot{\varepsilon} \chi 01 \sigma^{\prime} \ddot{\alpha} \sigma \tau \rho \alpha\right)$.

Automedes' likeness to the (literally) star performer in a choral band extends to the delineation of the events - a virtual victory catalogue - in which he triumphed. First off is his discus throw $(30-32)$, the moment that supplies the tenor for the lunar simile. The description privileges circularity: the athlete in the midst of his fellow contestants stands equivalent to the moon with its circlet of subordinate astral bodies as he throws the rounded discus (a move which requires the body to describe an arch and then turn about its axis) while positioned in the center of the crowd sounding its acclaim. The scene recalls not just Odyssey 8.370-380, where the chorus encircling the troupe's star performers staging their acrobatic pas de deux likewise raises an approbatory sound; if the Homeric account of the chorus on Achilles' shield (cited in section two) reflects traditional notions of choral dancing, then the spin of the potter's wheel ( $\tau$ poxóv, Il. 18.60o) supplies a canonical comparandum for the gyrating

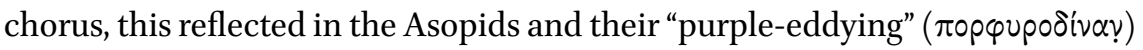
father. ${ }^{29}$

Two further details in the visualization draw on choral terminology, practices, and audience response. Even as Automedes' bodily form is "wondrous"

\footnotetext{
$27 \quad$ For discussion and examples, see Ferrari 2008 and Csapo 2008.

28 For the fragment as chorally performed, see Lardinois 1996: 161-162.

29 For $\delta เ v \varepsilon \dot{\omega} \omega$ as an indicator of circular (and, in his view, dithyrambic) dancing, see Csapo 1999-2000: 418-424 and 2008: 273-274.
} 
$\left(\theta \alpha \nu \mu[\alpha] \sigma \tau \sigma^{\prime}, 31\right)$ in the eyes of the spectators, so thauma is Odysseus' sensation as he watches the Phaeacian youths dance ( $\theta \alpha \dot{v} \mu \alpha \zeta \varepsilon \delta \dot{\varepsilon} \theta \nu \mu \hat{\omega}, O d .8 .265)$, a response shared by the Ionians gathered on Delos who witness the extraordinary and paradigmatic song-dance of the Deliades, styled a "great thauma" in and of itself (Hymn. Hom. Ap. 156). ${ }^{30}$ Most striking of all is the unprecedented noun that Bacchylides selects for Automedes' wrestling moves, $\dot{\alpha} \mu \dot{\alpha} \rho \gamma \gamma \mu \alpha(36)$. Here, I suggest, the poet nods to a second Sapphic intertext, the evocation of Anactoria at the close of fragment $16 \mathrm{~V}:{ }^{31}$ recalling the departed maiden, the persona loquens describes her longing to see "the desire-causing step and

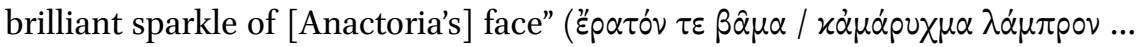
$\pi p \circ \sigma \omega \dot{ } \pi \omega, 17-18)$. The snapshot recalls the girl as she once performed as the leader of the ensemble, endowed, again, with the sparkle distinct to choral dancers; ${ }^{32}$ already in Homeric song and the hymnic repertoire, the cognate noun $\mu \alpha \rho \mu \alpha \rho \gamma \eta \dot{n}$ appears in the formulaic phrase $\mu \alpha p \mu \alpha \rho \gamma \gamma \alpha i$... $\pi \circ \delta \hat{\omega} \nu$, where it evokes the twinkle emanating from a dancer's feet as he/she performs as chorus member or choregos (e.g. Od. 8.265, Hymn. Hom. Ap. 203). Bacchylides may also anticipate the soon to be echoed Ehoiai in his diction here: $\dot{\alpha} \mu \dot{\alpha} p u \gamma \mu \alpha$ finds a still closer match in the formulaic phrase so frequent in the Catalogue of Women, Xapi $\tau \omega \nu ~ \alpha \mu \alpha p u ́ \gamma \mu \alpha \tau \alpha$, an expression repeatedly applied to heroines celebrated for their beauty. As Fearn comments, Automedes is "thus attracted into the language register associated with the kinds of feminine mythological archetypes who appear in Bacchylides' central myth, the Asopids,"33 and, I would add, more expressly to their Pseudo-Hesiodic representation. If Fearn's further suggestion that we might imagine Automedes as a member of a group of youths charged with celebrating the local heroines in choral performances is correct, ${ }^{34}$ then the mythical and real-world choruses become still more closely affiliated; just as such epichoric groups danced and sang on behalf of Aegina and her sisters on that island, ${ }^{35}$ so the Phleians may have done the same for the Asopids.

30 For thauma as a prime response to choral performances, see Neer 2010: 62-63 citing Bacchyl. 17.117-139 SM and Kurke 2012: 223, 227.

31 Also cited by Fearn 2003: 364 in passing; see too Cairns 2010: 256.

32 Typically Sappho reworks the hexameter formula, attributing the sparkle to the face while replacing the expected "feet" with the reference to the dancer's step.

33 Fearn 2003: 364. Very relevant is Fearn's further point that the "objectification" of Automedes positions him, like the Asopids, as a focus of erotic longing; that role is also suited to my reading of the laudandus as chorus leader insofar as choristers regularly express desire for their choregos.

34 Fearn 2003: 364.

35 See Steiner forthcoming for the Aeginetan choral celebrations. 
Commentators regularly observe that the Hesiodic Catalogue still more fully informs the final work considered here, this one composed by a poet who, like the Catalogue's supposed author, was native to Boeotia. Of course any mention of Corinna comes surrounded by debates concerning her date, the manner in which her songs were performed, and their intended audience, and I make two assumptions, closely argued for by other scholars, ${ }^{36}$ in the reading that follows: first, that Corinna belongs to the fifth century, and second, that her poems were most likely composed for choruses of parthenoi in Tanagra and perhaps elsewhere in Boeotia. Among the more extensive fragments is the socalled "Daughters of Asopos," a work whose extant portion occupies columns two to four of fragment 654. The Asopids are introduced in the early portion of the text, presented as a list narrating the abductions and marriages of at least some of the nine that the lines then number. The term $\hat{\omega} \nu$, "of these," suggests the start of the inventory, with Aegina in first position, then followed, in rapid succession, by Corcyra, Salamis, "lovely Euboea," Sinope and Thespia:

\begin{tabular}{|c|c|}
\hline$\hat{\omega} \nu " H \gamma[\iota \nu \alpha \nu$ & $\gamma \varepsilon] \nu \varepsilon^{\prime} \theta \lambda \alpha \nu$ \\
\hline$\Delta \varepsilon \dot{\varsigma} \varsigma[$ & $\dot{\alpha}] \gamma \alpha \theta \omega \hat{\omega} \nu$ \\
\hline$\pi \alpha \tau p \bigcirc[$ & $\dot{\varepsilon}] \varsigma$, \\
\hline Kopxoú [pav & $\left.\dot{\varepsilon} x x^{\prime} \Sigma \alpha \lambda \alpha \mu \hat{\imath}-\right]$ \\
\hline 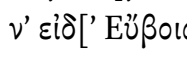 & 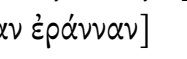 \\
\hline$\Pi \circ \tau \iota[\delta \alpha \omega \nu x]$ & 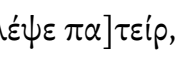 \\
\hline$\sum \iota \nu[\dot{\omega} \pi \alpha \nu \delta \dot{\varepsilon}$ & $\left.\Lambda \alpha \tau 0^{\circ} \delta \alpha\right] \varsigma$ \\
\hline$\Theta \dot{\varepsilon} \sigma\left[\pi \iota \alpha \nu \tau^{\prime}\right.$ & $\varepsilon^{\prime \prime} \chi \omega \nu \cdot$ \\
\hline
\end{tabular}

Of these (daughters) Zeus, giver of good things, (took) his child Aegina ... from her father's ... while Corcyra (and Salamis) and (lovely Euboea) (were stolen) by father Poseidon, and (Leto's son) is in possession of Sinope and Thespia ...

36 Here I follow, among others, Stehle 1997: esp. 101-104; Larson 2002; Collins 2006: 19-20 (with an overview of the argument); Lardinois 2011: 165-168. The case for the choral character of Corinna's poetry rests on admittedly slender grounds. Fr. 655.1-16, which opens with an invocation to Terpsichora ("she who delights in choruses") and is spoken in the voice of a poet or that of the collective chorus, which announces that it proclaims the legends of its homeland, Tanagra in Boeotia, offers the most compelling evidence. In Stehle's reading, the fragment suggests that Corinna addresses two audiences for whom different songs are performed: first the collective audience made up of the women of Tanagra, and then the parthenoi with whom the stories "from our fathers' time" seem to be connected. 
As Campbell's note points out, the catalogue would have ended with Tanagra, whom Hermes stole. Fresh enumerative design follows when the singers remark at $12-18$ of the next column:

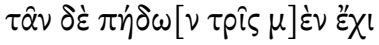

$$
\begin{aligned}
& \Delta \varepsilon \dot{\varsigma} \pi \alpha \tau \varepsilon i[\rho \pi \dot{\alpha} \nu \tau \omega] \nu \beta \alpha \sigma i \lambda \varepsilon \dot{\zeta} \varsigma \text {, }
\end{aligned}
$$

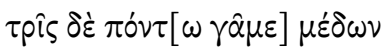

$$
\begin{aligned}
& 15 \Pi[0 \tau 1 \delta \dot{\alpha} \omega \nu, \tau] \alpha \hat{\alpha} \nu \delta \dot{\varepsilon} \delta 0 \nu \hat{\imath} \nu
\end{aligned}
$$

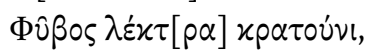

$$
\begin{aligned}
& \tau \hat{\alpha} \nu \delta^{\prime} \text { ' } \alpha \nu \text { Mń[ }[\alpha \varsigma] \dot{\alpha} \gamma \alpha \theta \dot{\alpha} \varsigma \\
& \pi \hat{\jmath} \varsigma^{\prime} \mathrm{E} p \mu \hat{\alpha} \varsigma^{\circ}
\end{aligned}
$$

And of your daughters father Zeus, king of all, has three; and Poseidon, ruler of the sea, married three; and Phoebus is master of the beds of two of them, of one Hermes, good son of Maia.

A marked degree of the repetition characteristic of lists structures this account, with $\tau \hat{\alpha} \nu$ $\delta \dot{\varepsilon}$ standing at the start at each entry naming a god and the number of his conquests, almost like an inscribed victory list. In counterpoint to this homogeneity, but very much in keeping with catalogue design, the numbers diminish, three apiece for the two "top" deities, two for Apollo, one for Hermes. The close of the list is, typically again, resumptive, reassembling the sisters into their collective nine.

As already noted, it has been commonplace to remark on the broader overlap between the subject matter, theme, and arrangement of Corinna's extant poetry and that of the Pseudo-Hesiodic Catalogue, and nowhere more than in fragment 654, a composition whose themes are very much in sync with those of its hexameter precedent. The later poet's concern with genealogy and ancestry through maternity emphatically here recalls the Ehoiai, and Jennifer Larson notes that line 9 "hints at familiarity with the Catalogue"; as she further remarks, "both the Catalogue and Asopid daughters provide a marked, hierarchical catalogue of progenitor gods who beget a race of semidivine heroes." ${ }^{37}$ The enumeration of the Asopids also points back to the Odyssean catalogue of heroines at 11.225-332, and not least for the Boeotian focus prominent in both; among those whom Odysseus encounters is Antiope, another daughter of Asopos in the Pseudo-Hesiodic Catalogue (frs. $38-42$ ), who has strong links to 
Boeotian sites and cults. The sequence of four that follows-Alkmene, Megara, Epikaste, and Chloris-all share connections to the region. ${ }^{38}$

But as I argued for Bacchylides' composition for Automedes, Corinna's song simultaneously taps into the chorality associated with the Asopids in the lyric and visual traditions. With Tanagra concluding the enumeration, the initial list seems designed as a sequence culminating in a final city, singled out by the performers for the closing and privileged position. Since Tanagra was the site of choral performances of Corinna's poetry by parthenoi in fragment 655 (see n. 36), the passage offers a fresh instance of choral projection, with the role of the Asopids reenacted by the latter-day ensemble of maidens in Tanagra also on the threshold of marriage and whose choregos, perhaps decked out in extra finery or with an added accessory, takes on the leading role afforded the local and hence preeminent daughter. ${ }^{39}$

Putting all these pieces together, the Asopids seem firmly grounded in two generic traditions, both visible in the songs of Bacchylides and Corinna. First, that of the genealogical poetry - the sources' chief interest in the maidens seems to be their role as the mothers of the heroes whose lineage reaches down to historical times - that so readily lends itself to catalogue form. The tendency to figure the river's many daughters in the linear structure characteristic of these poetic (and inscribed) lists extends to visual representations: Asopos and his daughters appeared in the now lost bronze statue group that Pausanias saw at Olympia, which depicted Aegina being abducted from the company of her sisters; Pausanias names Nemea, Harpina, Corcyra, and Thebe, with Asopos seemingly positioned last in the line. The language of the passage, complete with the term $\delta\llcorner\alpha \varkappa \sigma \mu \varepsilon \dot{\varepsilon} \omega$ used in other sources for the marshaling-cum-arraying of choral processions, leaves no doubt as to the group's linear presentation while, perhaps, also reflecting the choral formation that the images' deployment brought to the visitor's mind (5.22.6.1-10):

The Philesians also dedicated a Zeus and the daughters of Asopos and

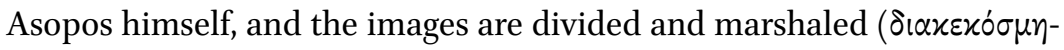
$\tau \alpha l)$ thus: Nemea is the first of the sisters and after her comes Zeus seizing Aegina; next to Aegina stands Harpina ... after her is Corcyra with Thebe next; last of all comes Asopos.

38 See Larson 2000: 198-200.

39 Beyond that fragment, we have no references to choral activity in Tanagra, whether by parthenoi or other groups; note, however, Calame 1997a: 135 n. 131, citing Schachter 19811994: 1.179-180 and 185-186. 
Presumably reading off each name as inscribed beneath the successive images, Pausanias effectively performs a mini-catalogue, complete with internal repetition and a superlative name cap for the last item listed, even as his enumeration might call a choral collective and its performance to mind. ${ }^{40}$

As for the second generic tradition in which Asopos' daughters are embedded, that of choral songs, some in the form of the partheneia performed by maidens in the regions with which the mythical sisters were most closely associated, others by youths equating themselves with those standing choruses, this can be explained on several grounds. First, most simply, because the Asopids form an epichoric company, as do the participants in the corresponding realworld ensembles. And second, because the heroines' "histories" offer a prime instance of the types of myths, themes, and concerns regularly articulated in partheneia, whose composers typically select topics and motifs calibrated to their singer-dancers' gender and time of life. Wayne Ingalls details the contents of such works - those of Alcman, Sappho, Tlesilla, and Corinna among them-and argues that the issue of female sexuality, its positive and negative consequences and the need for its containment, are writ large in these pieces that served a paideutic function for their performers and audiences. ${ }^{41}$ Suggestive of a song designed for a chorus of partheno $i$ is not only the subject matter of Corinna's fragment, a group of maidens destined for marriage and abstracted one by one from their sorority, but also its resolution. In the conversation between Asopos and a local seer in which the list just cited appears, the father learns that the gods will ultimately give him the compensation that recasts these abductions as sanctioned unions. ${ }^{42}$

It is here that the two poetic genres coalesce. It needs no demonstration that unions between maidens, gods, and heroes, some legitimate and orderly, others marked by violence or the transgression of regular matrimonial practices, are the central concerns of the Pseudo-Hesiodic Catalogue. Courtship protocols both observed and violated (so the tale of Mestre) and marriage contests (that of Helen most obviously) also occupy a major place in the work, ${ }^{43}$ as they do in the extant poetry composed on behalf of maiden choruses. In light of their suit-

40 Cf. the Geneleos group from the Heraion at Samos depicting the dedicator's three daughters who are, in the view of Karakasi 2003: 28-29 and Day 2010: 193, depicted as dancers in the choruses that celebrated the goddess; here too a viewer, moving from one figure to the next as he/she reproduced the dancers' processional motions, would read off the identifying inscriptions on the images' bodies (see $I G$ 12.6.2.559 for these), effectively enunciating a genealogical catalogue.

41 Ingalls 2000.

42 See Lardinois 2011: 166.

43 As closely argued and detailed by Ormand 2014. 
ability to parthenaic choral performances, it does not seem wholly implausible that the Pseudo-Hesiodic Catalogue's presentation of the Asopids, along with other maidenly sororities, draws on the lyric repertoire and may have incorporated the choral compositions' diction, imagery, and themes into the hexameter account.

\section{Choral and Catalogue Morphologies}

If, as argued above, archaic and early classical sources demonstrate intimate connections between the "set-piece" catalogue and its choral performance, toggling together generic elements from each tradition within their songs in ways that amplify and extend the scope of their accounts of individuals and events, then how might we explain that affinity? Moving beyond the intuitive notion that a multiplicity of items requires plural performers, do deeper relations exist between catalogue poetry and choruses and are these discernible in the textual and visual evidence? ${ }^{44}$ In attempting some answers, I focus on the "morphology" (to borrow the term of Claude Calame) ${ }^{45}$ of the chorus-its make-up, the interactions between its different members, organization, formations, and movements through space-and suggest that catalogues in archaic sources possess closely corresponding features.

In Benjamin Sammons' definition, a catalogue, whether made up of two or multiple members, is "a list of items which are specified in discrete entries ... no explicit relation is made except for the shared suitability to the catalogue's specified rubric." ${ }^{\text {"6 }} \mathrm{He}$ further defines a rubric as "a stated category or class which legitimates the involvement or exclusion of potential items."47 This "rubric" squares with Calame's delineation of the three most broad-based features that determine membership of a chorus: ties of kinship, locality, and age, ${ }^{48}$ each of which maps still more narrowly onto common criteria for inclusion in a catalogue. Just as so many real and mythical choruses form sororities with a parent or other relation by way of a lead member (in addition to the Muses and Graces,

44 Here I try to build on the insights of Carruesco 2010 and his more generalized and textbased explanation; the overlap is based on "la similitud morfólogica de una unidad articulada a partir de una pluralidad de miembros, como en el más profunda de la función, que es precisamente la capacidad activa de generar esa articulación" (2010: 386).

45 Calame 1997a.

46 Sammons 2010: 9 (emphasis in original).

47 Sammons 2010: 9 .

48 Calame 1997a: 26-34. 
we encounter the Pleiades, Nereids, Asopids, and Hyades), so kinship ties unite the members of the extended family groupings that structure the Catalogue of Women, or the list of ancestors in Glaucus' genealogical recitation at Iliad 6.145211. There are any number of examples of "epichoric" choruses, among them the Deliades, Caryatides, and the maidens on Aegina in Bacchylides 13, who celebrate a local $\left(\tau^{\prime} \dot{\varepsilon}\left[\pi \imath \chi \omega p^{\prime} \alpha \nu, 92\right)\right.$ festival in song and dance and style themselves neighbors (89). Analogous to these are the entries in some catalogues, or parts thereof, whose presence is determined by geographical proximity: the suitors enumerated by Telemachus at Odyssey $16.247^{-253}$ all come from nearby islands (they belong to the same age class too) while the several women clustered at the start of Odysseus' heroine list (Od.11.225-332) share a Boeotian origin.

Beyond membership of an overarching "rubric," studies of the catalogue in early poetry have isolated a variety of syntactic structuring principles. Most simply, parataxis, sustained by bare connectives, these often repeated in a rhythmic sequence marked by the occurrence of the expression in the same position in the hexameter line. While Dolon's list of the Trojan allies in Iliad 10.428-434 uses the conjunctions $x \alpha$ í and $\pi$ pós to link the different contingents introduced sequentially, $\tau \varepsilon$ and $x \alpha$ í, sometimes combined, coordinate the list of Nereid names at Iliad 18.38-49. Ticking off his liaisons in Iliad 14.317-327, Zeus introduces each conquest with ovंठ́, anticipating the structure of the second catalogue in Alcman's first Partheneion (64-77). Representations of choruses on Geometric and early classical vases exhibit a corresponding parataxis through visual means: using repeated elements to link the totality of choreuts into an ensemble, they simultaneously distinguish one performer from the next by giving each some particularized and on occasion unique feature, much as epithets singularize each individual or item in a poetic catalogue. The chorus of the "twice-seven" occupying the top band of the familiar François Vase of ca. 570 (fig. 5.1), ${ }^{49}$ and whose storied bands stacked one onto the other recall the catalogue of scenes on the Iliadic shield of Achilles, ${ }^{50}$ offers a prime example of this simple arrangement. Each chorister wears a different dress and bears a different name, while interlinked hands connect each discrete member to the adjacent individual. Much like the epithets given each Hippocoontid in the first of the two catalogues in Alcman's first maiden song (1-12) are the different shield devices distinguishing each dolphin rider in the chorus on a red-figure psykter by Oltos of ca. $5^{20-} 510$ (fig. 5.2 ); ${ }^{21}$ in this instance too, indi-

49 Florence, Museo Archeologico 4209.

50 Notopoulos 1949: 22 styles the work the "locus classicus for parataxis in vase painting."

$5^{1} \quad$ New York, Metropolitan Museum 1989.281.69. 


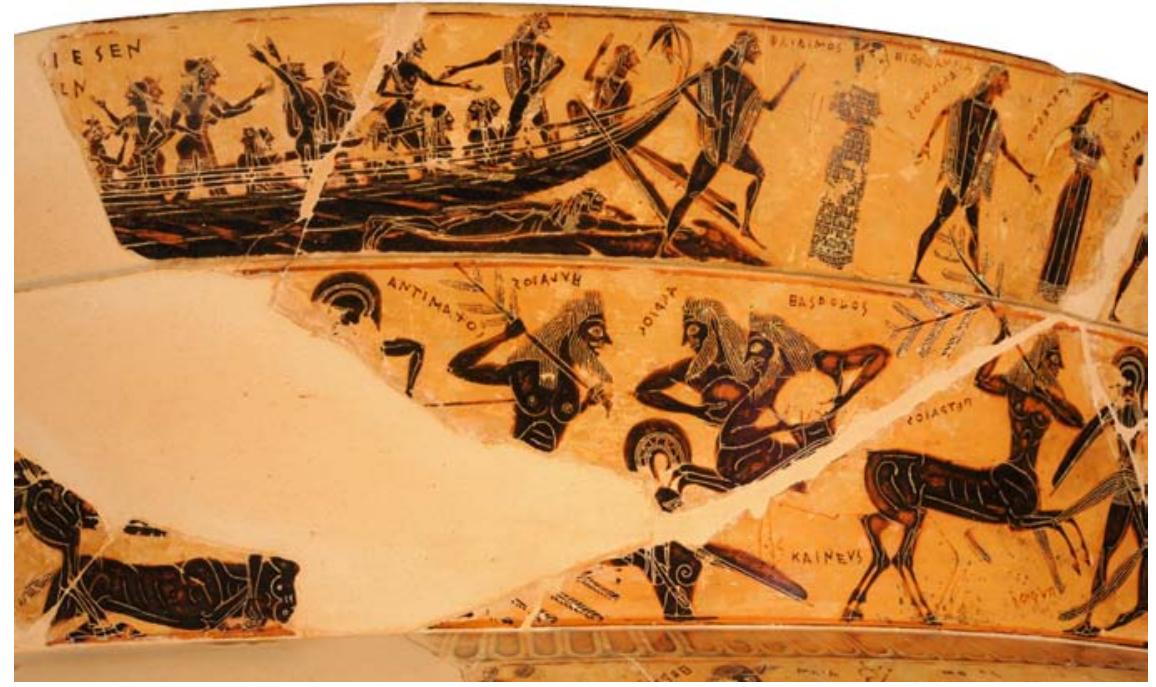

FIGURE 5.1 Attic black-figure volute krater (François Vase), ca. 570 BCE. Florence, Museo Archeologico 4209

PHOTO COURTESY OF SOPRINTENDENZA PER I BENI ARCHEOLOGICI DELLA TOSCANA

viduation coexists with the homogeneity established by the riders' identical poses, mounts, and costumes, and the refrain inscribed in the same position above each rider, which functions like the repeated elements observed in the shaping of poetic catalogues. Enunciation of the inscriptions would reinforce the collective quality of the chorus, the blending of all voices into one and their rhythmic unity: each dipinto reads "on the dolphin."

A second simple organizational device within lists is a "first to last" structure, accentuated by such temporal expressions as $\pi \rho \hat{\omega} \tau \circ \varsigma$, है $\pi \varepsilon \imath \tau \alpha$, and $\tau \dot{\prime} \tau \varepsilon .{ }^{52}$ This may also coincide with another frequent feature of Homeric catalogues, the suggestion that the speaker visually scans the scene, whether in the mind's eye and/or while performing the list. Both focalization and linearity are emphatic in Odysseus' enumeration of heroines before the Phaeacians ( $\mathrm{Od}$. 11.225-332). Not only does the speaker introduce each of the women by remarking that he "saw" her, but the preliminaries to the successive encounters alert us to the interlocutors' organization into a line. Initially appearing in a disorderly mass and in great numbers ( ${ }^{\circ} \sigma \sigma \alpha l, O d$. 11.227, this a standard term for introducing a catalogue), the shades circle around the pit (so ' $\alpha \mu \varphi^{\prime}$ at 228), and assemble 


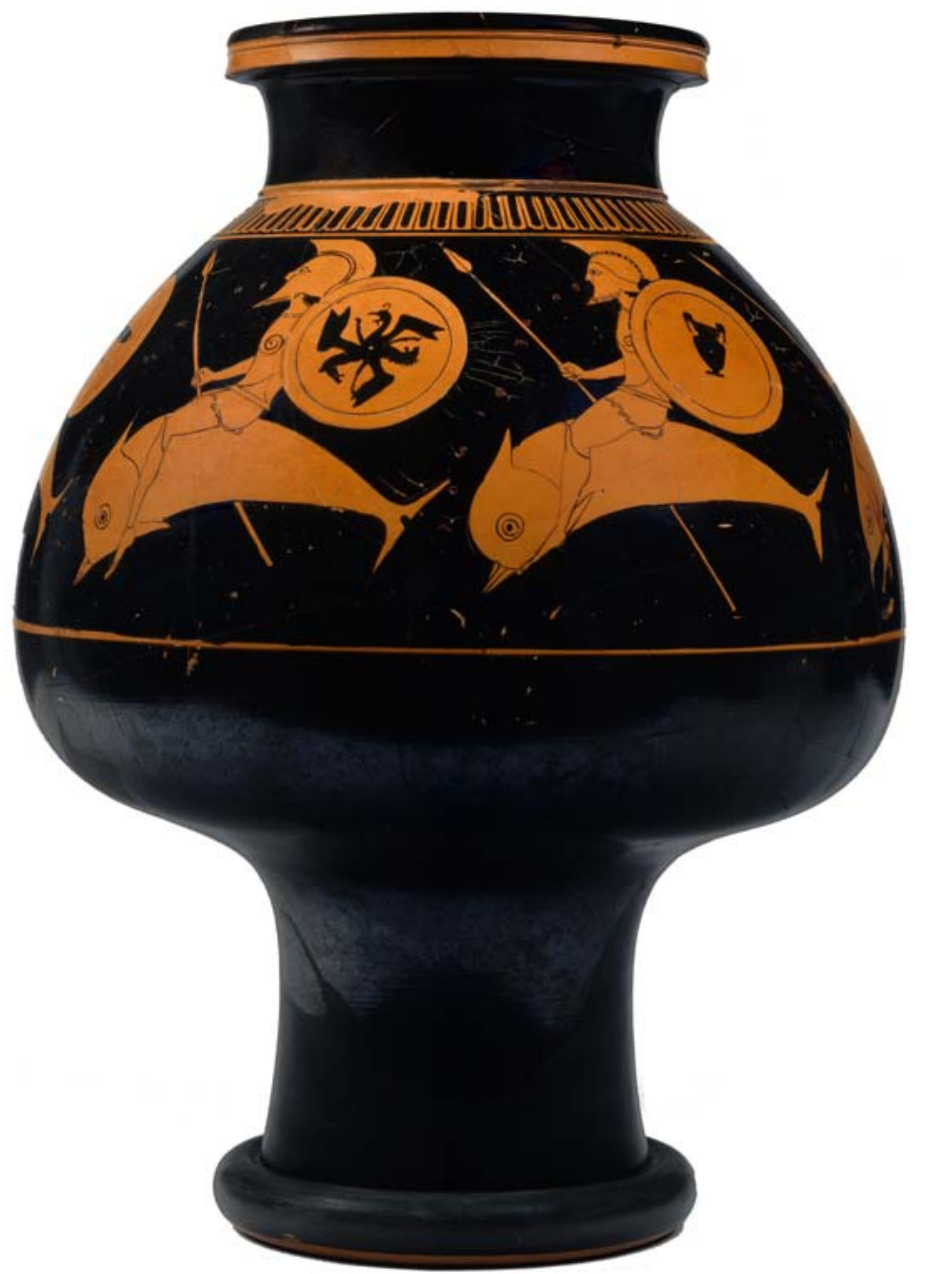

FIGURE 5.2 Attic red-figure psykter attributed to Oltos, ca. 520-510 BCE. New York, The Metropolitan Museum of Art 1989.281.69 PHOTO COURTESY OF THE METROPOLITAN MUSEUM OF ART / ART RESOURCE, NY

in crowds ( $\left.\dot{\alpha} 0 \lambda \lambda \varepsilon \dot{\varepsilon} \varepsilon \eta_{\gamma} \gamma \varepsilon p \varepsilon \dot{\varepsilon} \theta 0 v \tau 0,228\right)$, remaining undifferentiated until Odysseus positions them in linear order, "one by one" ( tioning each shade in turn.

Again choral morphology — each chorister positioned one after the nextoffers a close analogue. In the case of Alcman's parthenaic ensemble, its second catalogue may reflect the performers' current formation; quite plausibly, the singers list their members' accessories and names in accordance with their position within the chorus line, much as with the ordering of the inscribed 


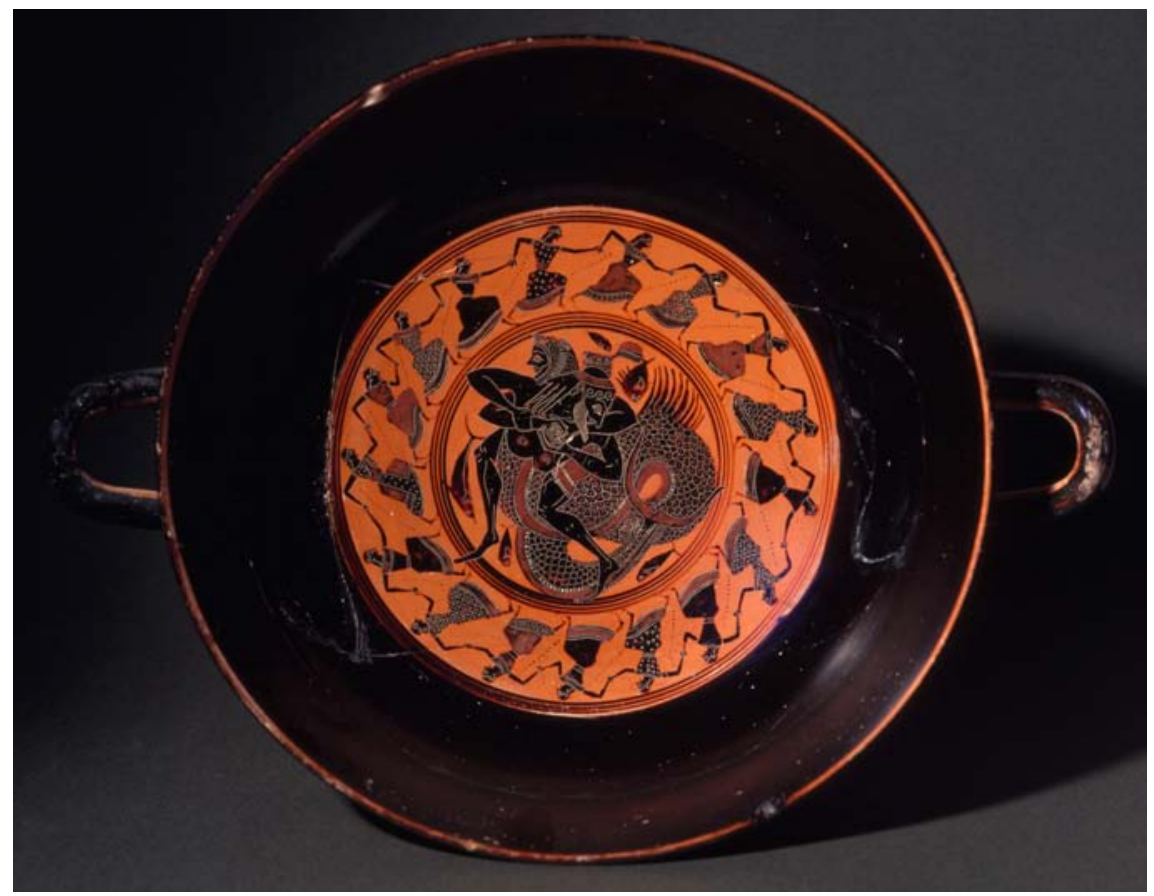

FIGURE 5.3 Attic black-figure Little Master lip kylix, ca. 55 BCE. Tarquinia, Museo Nazionale Tarquinese RC 4194

PHOTO COURTESY OF NimATALlah / ART RESOURCE, NY

names on the François Vase. ${ }^{53} \mathrm{~A}$ mid-sixth-century cup from Tarquinia rings a change on the iconographic design (fig. 5.3). ${ }^{54}$ In his depiction of a chorus of Nereids circle-dancing around the vessel's rim while Heracles wrestles with Triton in the tondo, the artist visually echoes the crook of the nymphs' arms by placing what look like sequences of letters in identical position between each pair and that seem to name, just as Hesiod does in the Theogony (see below), each of the Nereid dancers. On closer inspection, the notations turn out to be no more than nonsense inscriptions that reinforce the performers' homogeneity. But individuation also enters into the design: each of the nymphs wears a differently patterned gown.

Beyond these straightforward devices, many lists display a more refined and complex artistry. Poets may introduce hierarchy and a progressive diminishment or elaboration through the addition or subtraction of epithets and/or by

53 For the intensely "spectacularized" nature of a chorus whose members are both viewers and more frequently viewed, see Swift 2016b. Note too Peponi 2004.

54 Museo Nazionale Tarquiniese RC 4194. 
including additional information concerning more privileged member(s). In the terms Christopher Faraone uses of this gradual auxesis, and the correspondingly expanded space allotted an item standing solo in a line or extending over more than one, such lists culminate in a "superlative name cap" flagged by $\pi \lambda \varepsilon \hat{-}$ $\sigma \tau \sigma \nu, \mu \alpha \dot{\lambda} \mid \sigma \tau \alpha$, or other superlatives. ${ }^{55}$ There is ranking here, a move from less significant objects, places, or individuals to those whose distinction depends, among other properties, on their value, superior craftsmanship, social status, and prior or subsequent importance in the narrative. Often the individual singled out occupies the first or last place in the birth order, a placement that coincides with his or her position in the list; so Cronus is both last born of the offspring of Oceanus and Gaia and the closing entry in that catalogue. Indeed, the passage well illustrates the ordering devices that Faraone identifies: a simple connective joins the first eight names, distributed four per line, while only two names, complete with epithets marking their greater importance, appear in the third line; granted two lines and two superlatives is the final child, who will succeed his father (Hes. Theog. 133-138).

Artists deploy analogous devices to indicate hierarchies in choral collectives, similarly alerting viewers to divisions between one or several members and the rest. Painters distinguish the choregos most simply by assigning him or her the lead or last position in the line, a primacy sometimes underscored by the addition of an accessory, more elaborate clothing, or augmented stature. Preeminence within an overall unity appears on a black-figure kylix from Argos, dated to ca. $600-55$ o (fig. 5.4), ${ }^{56}$ where a single mantle covers nine female choristers with identically styled hair; at the line's head stands a maiden who, uniquely, carries a garland. The "specialness" accorded the third dancer on a late eighthcentury Geometric hydria from Aegina, ${ }^{57}$ whose skirt is chequered differently from those worn by the rest, might be a visual device for establishing leadership when the dancers form a ring, as they frequently do as they circle around the neck or shoulder of a vase. Faraone well explains the privileging of Calliope, introduced last and given an entire line with a superlative in Hesiod's list of the nine Muses at Theogony $76-79$, noting that it suits the thematics of the passage in which she appears. ${ }^{58}$ Kleitias, the painter of the François Vase, may be responding to the Hesiodic account (or to a work drawn from the same source as the Theogony) in similarly according front rank status to Calliope, while

Faraone 2013: 294, 295-298. Here I summarize Faraone's argument and draw on some of his examples.

56 Berlin, Antikensammlung F 3993.

57 Berlin, Antikensammlung F 31312.

$5^{8}$ Faraone 2013: 300-301. 


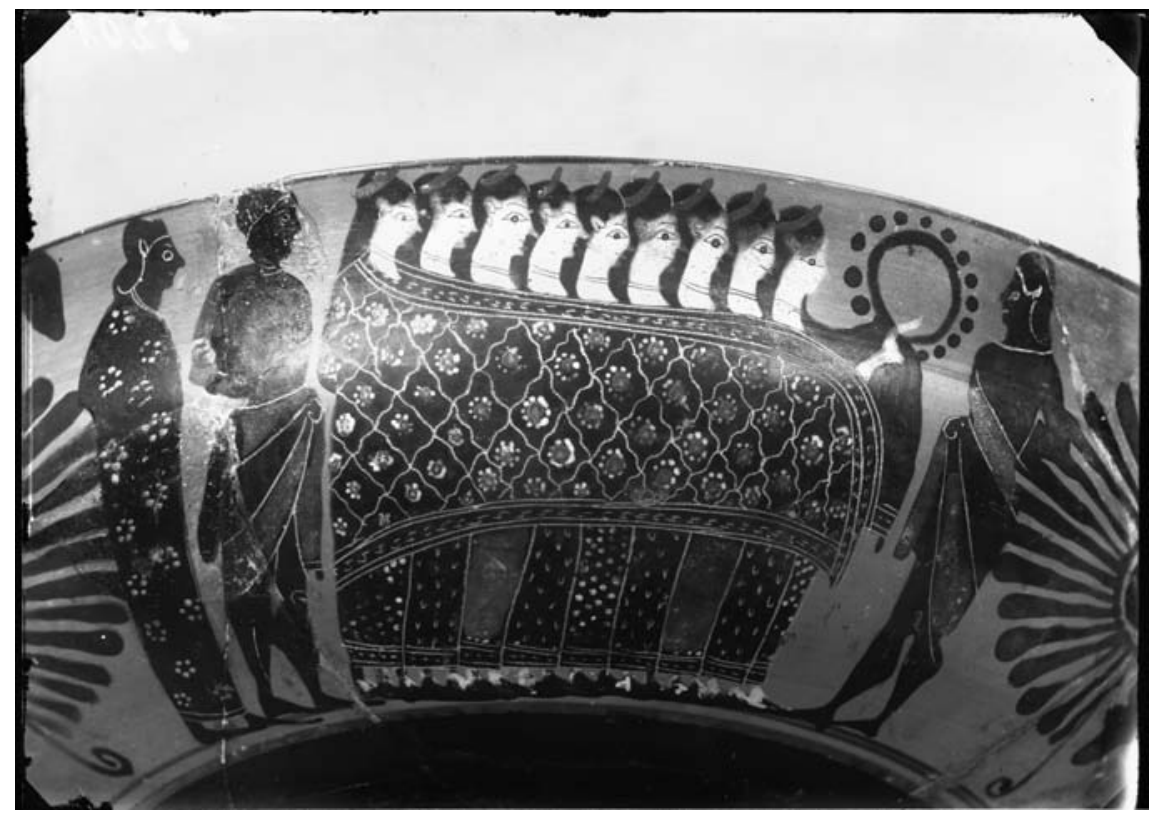

FIGURE 5.4 Attic black-figure kylix from Argos, ca. 6о0-550 BCE. Berlin, Antikensammlung Staatliche Museum F 3993

PHOTO COURTESY OF BPK BILDAGENTUR / ANTIKENSAMMLUNG STAATLICHE MUSEUM / ART RESOURCE, NY

also reworking the poetic template. Where Hesiod positions the preeminent goddess in the final marked position in the catalogue, the visual conventions informing the representation of choruses determine the placement of the figure labeled $\mathrm{Kal}(\mathrm{l})$ iope at the front of the troupe of Muses attending the wedding of Peleus and Thetis on the vase; so located, she occupies the spot reserved for the chorus-leader. Scanning the vase from left to right in accordance with the arrangement of the procession, the viewer would encounter this Muse as the terminus and culminating figure in the ensemble. ${ }^{59}$ Several further devices distinguish this goddess: standing separate from her sisters, she alone faces outwards and plays the syrinx.

The topmost band of the François Vase anticipates the arrangement in the wedding scene below, again signaling the primacy afforded the choregos, the correlate to the singling out of the catalogue's first or last entry. Whereas the other youths wear cloaks and himatia, processing empty-handed, Theseus, positioned at the head of the line, stands out by virtue of his full-length robe 
and the lyre that he carries. And while all the other names appear above the choreuts, similarly positioned, his alone occurs beneath, written retrograde. This visual particularizing of Theseus' identity concludes the written catalogue displayed within the scene: a viewer reading off the list of names, even reciting these in rhythmic fashion so that the sounds coincide with the chorus' processional step, performs a catalogue reminiscent of the enumerations in Alcman's first Partheneion. ${ }^{60}$ On a Corinthian aryballos dated to the early sixth century (fig. 5.5), ${ }^{61}$ image and text freshly declare the star role of the lead dancer/choregos; he too occupies the start of the chorus line, where, viewing from left to right, the audience sees him before the rest of the ensemble. Alone among his otherwise indistinguishable and still static followers lined up in pairs behind their leader, "Pyrrhias" is named in the accompanying inscription that accentuates the height of his leap, the tricky bibasis, and contrasts with the lettering that keeps the other dancers on the ground.

Ring composition and internal patterning act as other structural devices in poetic catalogues. The first occurs several times in the Theogony, as exemplified by the list of Nereids enclosed by the double mention of Nereus, "who bore them," at lines 240 and $263 .{ }^{62}$ The name of the last listed daughter, Nemertes, prepares the way in sound and sense for the second mention of her also "infallible" father by introducing the quality of "unerringness" that he possesses. Two rings, a larger one surrounding a smaller, structure the itemization of Oceanus' progeny, daughters and sons; lines 337 and $367-368$ frame the larger circle, while 346 and $362-363$ bookend the internal ring. A similar arrangement is visible in Alcman's first Partheneion, where chorus line and catalogue design coincide. Prior to its self-introduction, the chorus draws attention to its choregoi, first Hagesichora, then Agido; following the closure of the list of the individual choristers' adornments and names, the singers return to the point of departure, naming Hagesichora first and Agido second. An early seventh-century oinochoe from Pithekoussai (fig. 5.6$)^{63}$ supplies a visual parallel. Here two all

6o In several respects my reading complements that of Olsen 2015. As she argues, the scene carefully differentiates between the orderly chorus under Theseus' leadership and the more haphazardly arranged crew members still on the boat, who do not form part of the "twice seven" elite Athenians. Reinforcing the distinction, I would add, is the absence of the inscriptions identifying the crew members; perusing the vase, a viewer would be unable to "catalogue" these heterogeneous individuals.

61 Corinth, Archaeological Museum C 54-1.

62 See Faraone 2013: 308-309 for close analysis.

63 London, British Museum 1849,0518.18. The "archaizing" Minoan dress of the two female dancers suggests a Cretan scene, as does the gesture of the central figure, presumably Theseus, who places one of his hands on the breast of the figure to his left. 


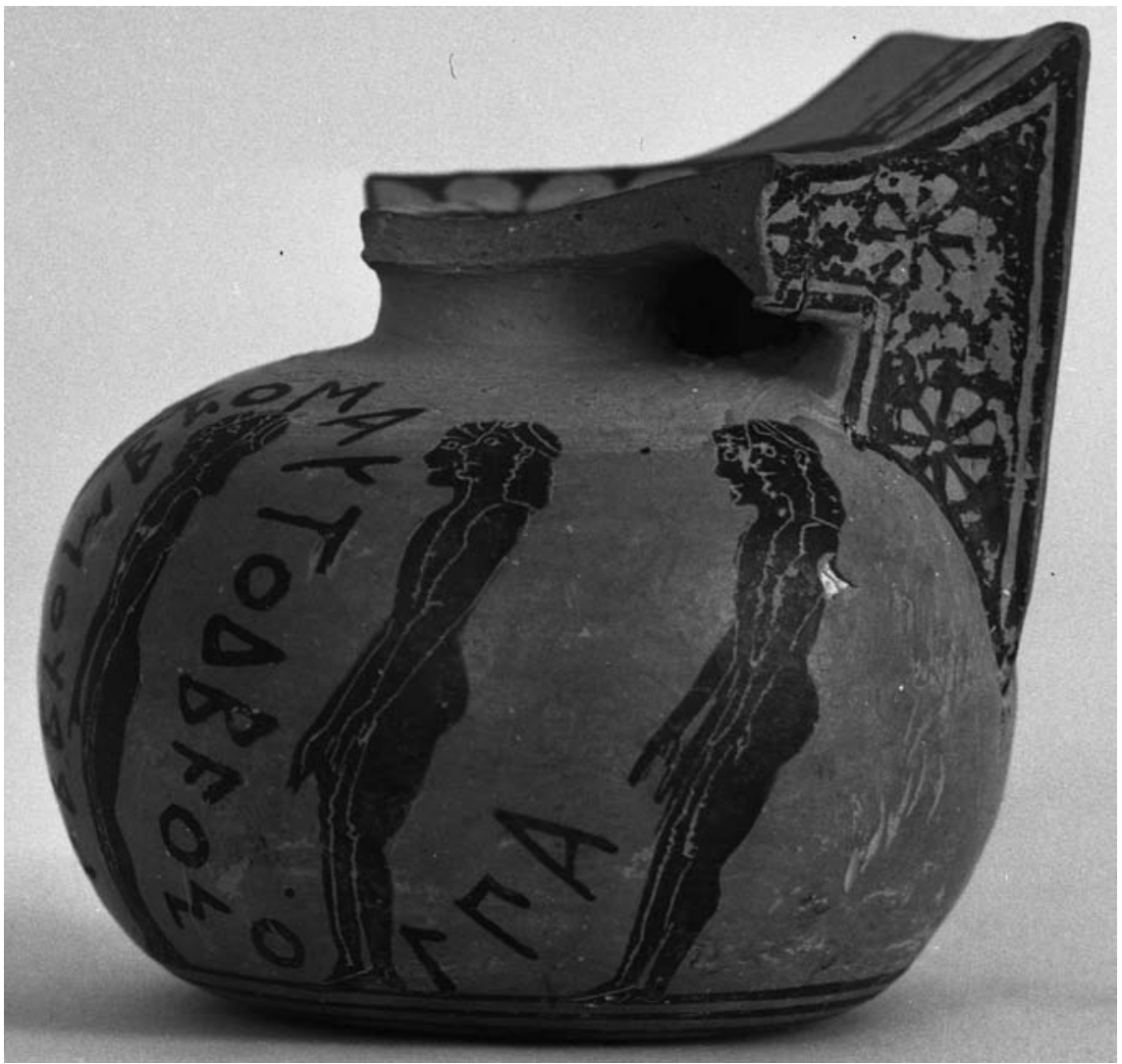

FIGURE 5.5 Middle Corinthian black-figure aryballos, ca. 56o BCE. Corinth, Archaeological Museum, C-1954-1 PHOTO COURTESY OF AMERICAN SCHOOL OF CLASSICAL STUDIES AT ATHENS, CORINTH EXCAVATION

but identical male figures, both executing the same step, frame what may be a representation of the geranos; reinforcing the symmetrical design are the oars each youth holds, which form the boundaries to the scene.

Additional patterns in poetic catalogues depend on verbal, acoustic, and rhythmic relations between the different parts. Anadiplosis, homeoteleuton, and isocolon are common stylistic features that create affinities between two or more items sometimes separated by other elements in the sequence. For all the apparent parataxis in the catalogue of Nereids at Iliad 18.38-49, the poet introduces internal combinations, repetitions, variations, and progressions through the placement of the names and their assonance and alliteration: so Kuposóxn $\tau \varepsilon$ appears at the end of 39 while Ku$\mu 0 \theta$ ó $\tau \varepsilon$ begins 41. Picking up on the suffix of her sister's name, but introducing a new prefix, 'A $\mu \varphi \mid \theta$ ón enters at 42 followed 


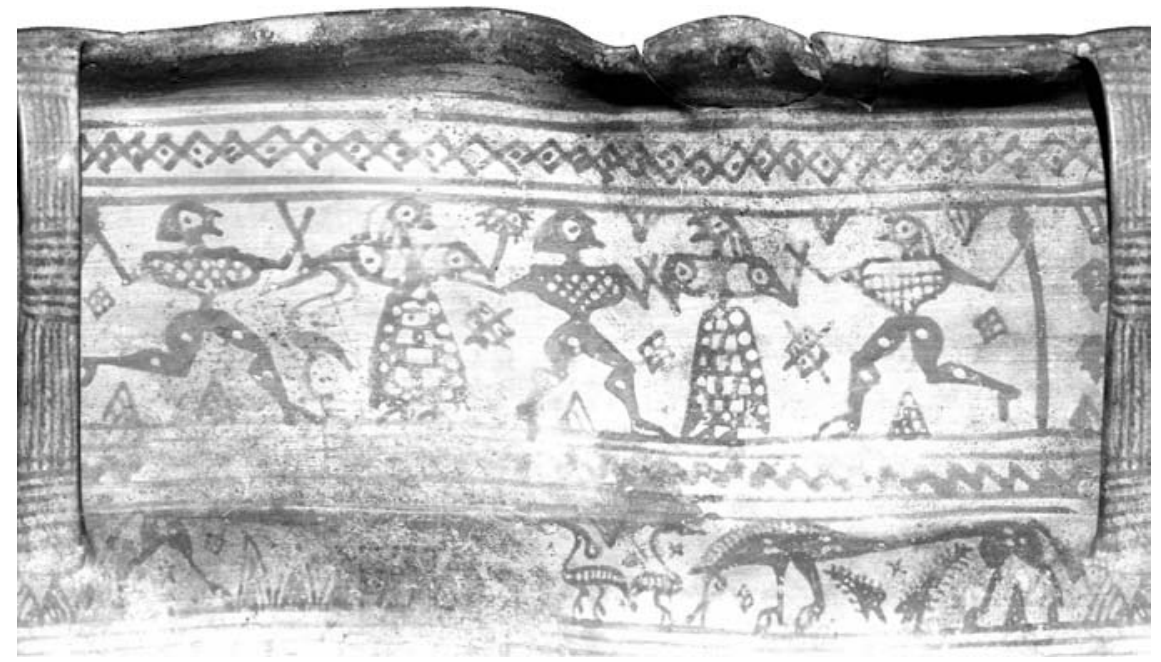

FIGURE 5.6 Late Geometric oinochoe (probably Etrurian), ca. 700-680 BCE. London, British Museum 1849,0518.18

PHOTO COURTESY OF TRUSTEES OF THE BRITISH MUSEUM

by the phrase $x \alpha i$ K $\alpha \lambda i \alpha \dot{\alpha} v \varepsilon \rho \alpha$ at 44; this nymph is then audibly paired with $\mathrm{K} \alpha \lambda$ $\lambda \iota^{\prime} \alpha \alpha \sigma \sigma \sigma \alpha$, also preceded by $x \alpha i$ and standing in verse-final position in 46 .

Such internal forms of iteration and alternation characterize visual representations of choral collectives, prompting viewers to perceive relations between discrete choreuts sometimes adjacent, sometimes positioned at different points in the file. A Polledrara hydria from the Grotta of Isis at Vulci, dated to ca. $575^{-} 55^{\circ},{ }^{64}$ shows on its lower register the dance executed by the Athenian maidens (probably, once again, the geranos with its twists, turns, and combination of linear and circular dancing) rescued by Theseus from the Cretan maze. Here the painter devises an interlinking arrangement evocative of the performance's intricacy: each chorister places one hand on the wrist of the next figure in the line while reaching with the other past her immediate neighbor so as to grasp the back-stretched arm of the next-but-one member of the troupe.

As the examples from the poetic sources already cited demonstrate, two chief structural principles are visible in catalogues from the hexameter repertoire: one linear or paratactic, which may additionally involve the progressive amplification or diminishment of the members in a ranked arrangement, the other determined by the creation of units of repetition and patterning that turn linearity into several circles or one grand ring. These overarching structures not

64 London, British Museum 1859,0227.50. 
only neatly dovetail with the two principal choral formations, processional and circular, but their frequent copresence within a single catalogue parallels the ways in which choral dancing commonly involves switchings-off between the performance modes. The Hesiodic presentation of the Muses' circular dance followed by a processional descent cited at this chapter's start corresponds to the motions of the chorus on the shield of Achilles in Iliad 18; here the youths and maidens sometimes turn in circles, as the simile of the spinning potter's wheel clearly indicates, and then regroup into lines or stichoi (5996o2):

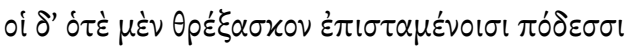 \\ 600

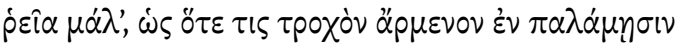

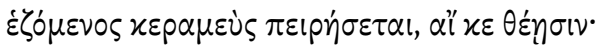

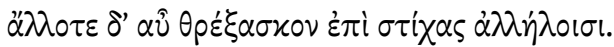

And at times they were running on well-skilled feet, very smoothly, as when a potter who is seated tests the wheel fitted to his hands, to see if it runs; and at others they were running in rows up to one another.

Nor do lines and circles exhaust the structural options available to archaic poets and artists in presenting catalogues and choruses. In one early instance, two groups of choral dancers, one female, the other male, circle around the neck of a loutrophoros of ca. 700 by the Analatos Painter (fig. 5.7$)^{65}$ while a phorminx player appears at the juncture between the two. So too on a diminutive lekythos by the Amasis Painter (fig. 5.8$)^{66}$ four youths and eight dancing maidens are shown around the shoulder of the vase; in this instance, a bride seated on a throne supplies the point at which the two groups converge. We might compare catalogues with gender divisions, such as that of the sons and daughters of Oceanus at Hesiod Theogony 337-370, where Tethys' role in giving birth to them (346) serves as the "meeting point" between the two sets of progeny. A second lekythos, also by Amasis and again with a nuptial theme, ${ }^{67}$ shows only women dancers; nine choristers grouped in two companies of three and six perform a ring dance, their subdivision indicated by the seated auletes and lyre-player bracketing each ensemble. As in the hexameter descriptions of choral dancing, linear and circular motion here coexist: the interlinked hands of the six,

65 Paris, Louvre CA 2985.

66 New York, Metropolitan Museum 31.11.10.

67 New York, Metropolitan Museum 56.11.1. 


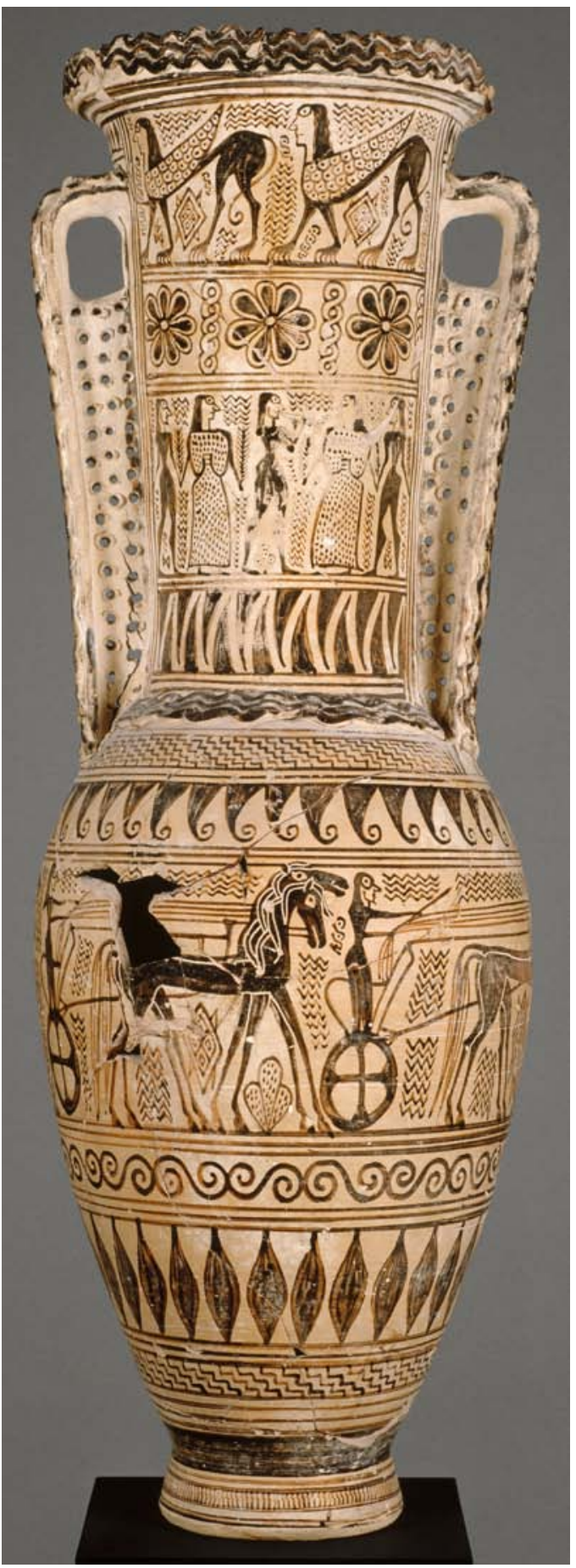

FIGURE 5.7

Protoattic black-figure loutrophoros attributed to the Analatos Painter, ca. 700 BCE. Paris, Musée du Louvre CA 2985 PHOTO COURTESY OF RMNGRAND PALAIS / ART RESOURCE, NY 


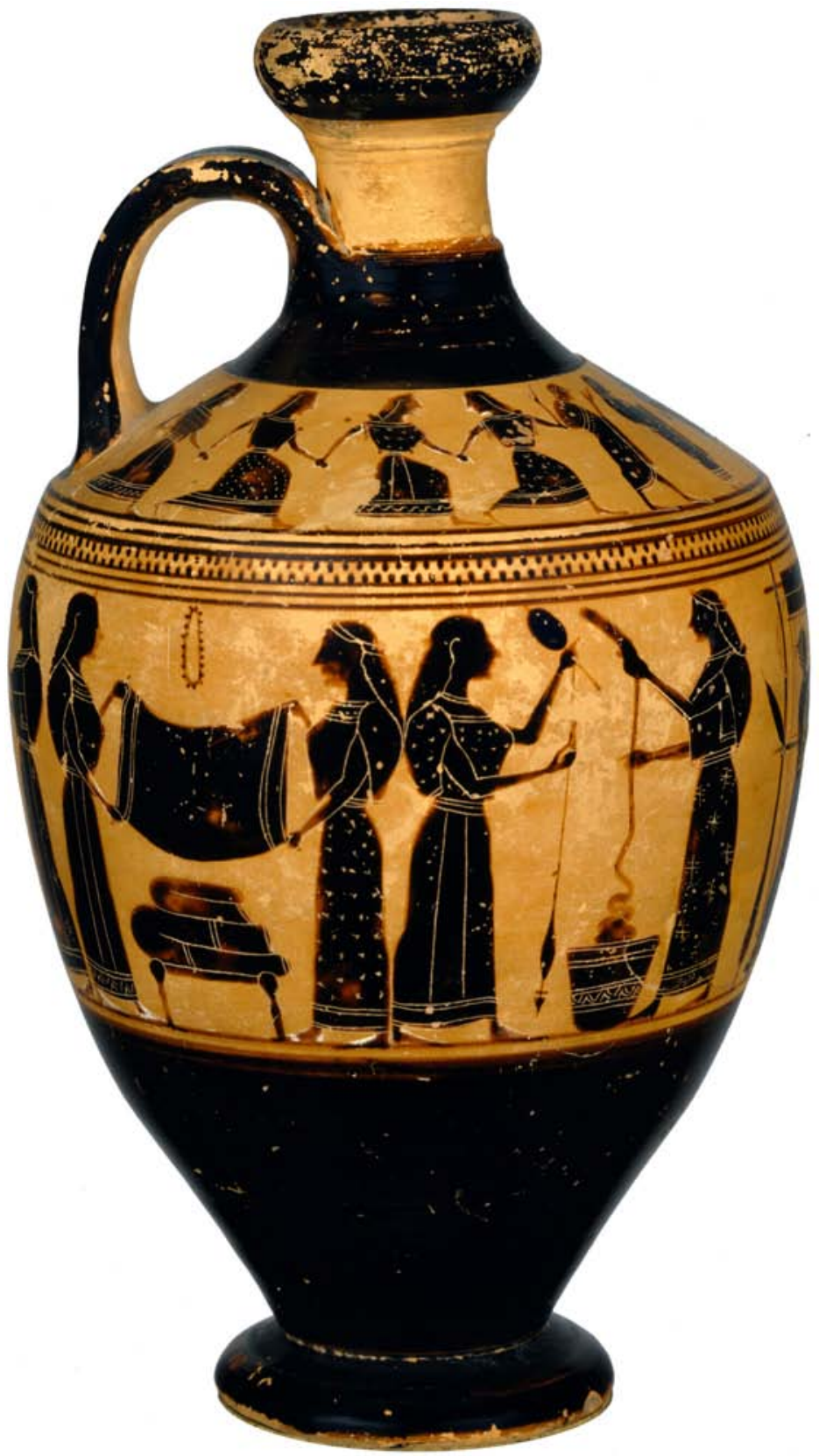

FIGURE 5.8 Attic black-figure lekythos attributed to Amasis, ca. 550-530 BCE. New York, The Metropolitan Museum of Art 31.11.10 IMAGE COURTESY OF THE METROPOLITAN MUSEUM OF ART / ART RESOURCE, NY 
together with the more vigorous step three of their number perform, suggest a ring dance while the smaller, measured motions of the trio evoke a processional formation. The musicians are the place at which the lines converge. These visual representations may propose a different choral formation: the convergence of two discrete choral lines so as to fashion a "v."68 Echoing this deployment is a passage from Euripides' Helen, where the chorus projects its identity onto a flock of cranes that adopts the same distinctive delta-shape in its migratory flights (1479-1484).

Granted, the reciprocal relations between choral compositions and catalogues identified through this chapter's course form part of a well-documented and much more widespread phenomenon, whereby different genres, some contemporary, some chronologically distinct, draw on, incorporate, and rework the diction, subject matter, conceits, performers, and performative contexts native to other generic traditions. But where, I have suggested, this particular instance of "generic contamination" and interchange stands distinct is in the deeper structural similarities that exist between the two modes explored here and that result from affinities discernible in the membership, organization, hierarchy, and the visual deployments common to both sets of collectives; this in turn scrambles straightforward notions of appropriation and borrowing and the agonism that so frequently characterizes relations between poetic traditions in antiquity.

The overlaps illustrated here open up a further possibility only touched on in passing and that would direct us towards the Nachleben of the intersections my argument has proposed. Subsequently preserved in the form of written lists, publicly displayed and inscribed in marble, bronze, or on some other durable matter, might a catalogue both visually and audibly (whether simply glanced at or enunciated à haute voix) have offered a synoptic, miniaturized, and metonymic reenactment of a choral performance? Well beyond this chapter's scope are the Hellenistic inscriptions that minutely record and inventory the choruses that took part in civic and Panhellenic festivals and sacred embassies, detailing the types of songs they sang, their accessories, the groups' positioning within a larger procession, the names of their leaders, provenance, and the rest. A consideration of the visual dimensions of these lists, their layout, the design of the lettering and placement of particular words, and an exploration of the units of rhythmic repetition they frequently include, might reveal additional areas where choruses and catalogues quite literally share a common

68 For discussion of this somewhat debated formation, see Crowhurst 1963: 293-298 and Calame 1997a: 37 . 
space. Through this assemblage of alphabetic notations, typically erected at the sites where the choruses would have performed and might still perform, both individuals and communities could maintain in "lithic" form the sounds and motions executed by a choral troupe and thereby acquire "scripts" for the reenactment of the event. 